\title{
Murâbaha Akdi Bağlamında Fıkıh Mirası ile İlişki Biçimimiz
}

\author{
Relationship of the Modern Jurists with the Classical Fiqh Heritage: \\ The Case of Murābaha
}

\section{İsmail CEBECI $\dot{I}^{*}$}

Öz: Modern meselelere fikhî çözüm arayışı sürecinde ne tür akıl yürütme ve hüküm üretme faaliyetlerinin yapıldığ 1 ve fikıh mirasının ve fikhi-tarihi tecrübenin nasıl değerlendirilip işleme koyulduğu çok önemlidir. Zira bu husus modern dünyada yaşayan fakihlerin (ve Müslümanların) yeni meselelere ve fıkıh mirasına yaklaşım tarzlarını ve ictihad usullerini anlamak için önemli bir harita sunar. Bu çalışmanın hedefi günümüz fakihlerinin modern murâbaha akdi bağlamında klasik fıkıh mirası ile ilişki biçimini ortaya koymak; başka bir deyişle murâbaha akdi üzerinden klasik fikıh mirasımızla kurulan ilişki biçimini okumaktır. Çalışmanın ana sorusu; "murâbaha akdinin oluşum ve gelişiminde ortaya çıkan hükümlerin üretim sürecinde klasik fıkıh mirası ile sağlıklı ve tutarlı bir ilişki biçiminden söz edilebilir mi?” sorusudur. Murâbahayı ele alan ve ayrıca klasik fikıhla ilişki şeklini irdeleyen önemli modern eserler bu çalışmanın temel hareket noktasını oluşturmaktadır. Bu bağlamda, günümüz fakihlerinin klasik fikha dair değerlendirme tarzları incelenerek murâbaha akdi özelindeki yaklaşımları analiz edilmektedir. Giriş bölümünün akabinde murâbahanın süreç ve yapı bağlamında klasik fikıhla ilişkisine değinilmekte, ardından murâbahanın modernize edilmesi sürecinde fakihlerin zihin dünyaları ve klasik fikha yaklaşım tarzları üzerinde durularak mezhep algısının konuya etkisi incelenmekte ve çalışma murâbaha akdi bağlamında klasik fıkıh mirası ile ilgili çıkarım ve tekliflerle sona ermektedir.

Anahtar Kelimeler: Murâbaha, fıkıh, fikıh mirası, klasik fıkıh, ictihad, İslâm iktisadı, İslâm ekonomisi, İslâmî finans, faizsiz bankacılık, akit teorisi

Abstract: This paper examines some of the methods of reasoning and judgment in the process of producing judicial (fiqhi) solutions for modern problems and the jurists' approaches to and evaluation of judicial-historical experience in this process. Such an examination may provide us with an opportunity to understand the approaches of the modern jurists (and Muslims) to the new issues/problems through fiqh heritage and their ijtihäd methodologies. This article aims to shed light on the relationship of the contemporary jurists with classical fiqh heritage in the context of the muräbaha contract. The study's main question is: "do the jurists maintain a sound and consistent relationship with the classical fiqh heritage in the process of the formation and development of the murābaha contract?" In terms of the study's methodology, a number of important modern fiqh books and articles on the murābaha such as al-Qaradāwī's Bay al-murābaha li-al-āmir bi al-shira kamā tujrīhi al-mașarif al-islāmiyya and its relationship with classical figh are the main starting point. The article, based upon a scrutiny of these primary sources, first lays out how the murābaha relates to the classical fiqh in

* Doç. Dr., Marmara Üniversitesi İlâhiyat Fakültesi İslâm Hukuku Anabilim Dalı Öğretim Üyesi. E-posta: ismailcebeci@marmara.edu.tr 
terms of process and structure. Further on, the paper analyses the contemporary jurists' approaches to the subject, particularly focusing on how their handling of the modern muräbaha reveal their mindsets and (changing) attitudes toward the classical heritage in the process of the modernization of muräbaha on the one hand, and the effect of their madhhab perceptions on the subject, on the other. The paper concludes with a number of specific propositions regarding the modern muräbaha's position vis-a-vis the classical fiqh.

Keywords: Murābaḥa, Fiqh, Fiqh Heritage, Classical Fiqh, Ijtihād, Islamic Economics, Islamic Finance, Interest-free Banking, Contract Theory

\section{Giriş}

Modern dönemde yapılan fikhî çıarımların niteliği; fikhî-tarihî tecrübenin ele alınma ve pratiğe aktarılma usulü ile yakından ilgilidir. Zira her geçen gün farklı alanlarda yeni meseleler ortaya çıkmakta ve bunların önemli bir kısmı klasik fikıh kaynaklarıyla irtibatland1rılarak çözüme kavuşturulmaktadır. Bu süreçte ne tür akıl yürütme ve hüküm üretme faaliyetlerinin yapıldığı ve fıkıh mirasının ve fikhî-tarihî tecrübenin nasıl değerlendirilip işleme konulduğu çok önemlidir. Çünkü bu husus modern dünyada yaşayan fakihlerin (ve Müslümanların) yeni meselelere ve fikıh mirasına yaklaşım tarzlarını ve ictihad usullerini anlamak için önemli bir harita sunar. Bu bağlamda, fikhî değişimin en canlı örneklerinden biri faizsiz finans alanıdır ve bu alanda kullanılan modern akitlerin oluşum sürecinde fikıh mirasının işleme konma usulü ziyadesiyle dikkat çekicidir. Zira bu akitlerin ortaya çıktığı ve uygulandığı bağlam ve sahip olduğu kurumsal zemin, geniş bir problemler kümesi ile yakın bir ilişki içindedir ve bu problemlerin birçoğu doğrudan veya dolaylı olarak klasik fikıhla irtibatlı bir biçimde ele alınmaktadır.

$\mathrm{Bu}$ çalışmanın ana hedefi günümüz fakihlerinin modern murâbaha akdi bağlamında klasik fıkıh mirası ile ilişki biçimini ortaya koymak; başka bir deyişle murâbaha akdi üzerinden klasik fıkıh mirasımızla kurulan ilişki biçimini okumaktır. Murâbaha akdi bu ilişkiyi görme açısından çok kıymetli analiz imkanları sunan bir araçtır. Zira klasik bir akitten revize edilip oluşturulan modern murâbaha akdi, mudârabe, müşâreke ve icâre gibi diğer benzer akitler içinde en çok değişim geçiren, pratikte en çok uygulanan ve fikhî ve iktisadî açıdan en çok tartışılan akit modelidir. Dolayısıyla murâbahanın günümüzdeki formuna ulaşana kadar geçirdiği sürecin ve güncel şeklinin klasik fikıhla ilişkisinin tahlil edilmesi hem faizsiz finans alanının, hem de genel olarak muamelâtın ve bir bütün olarak her türlü fikhî problemin konumunu anlamlandırma açısından çok önemlidir.

Makalede kullanılan bazı ibarelerin netleștirilmesi, çalışmanın sağlıklı bir şekilde takip edilip anlaşılması açısından önemlidir. "Fıkıh mirası" tabiri ile en geniş ölçekte, İslâm’n doğuşundan modernleşme sürecine kadar geçen dönemde ortaya çıkan fikıh birikimi kastedilmektedir. Bu uzun dönemin temel özelliklerinden biri, Müslümanların büyük oranda kendi belirledikleri bir dünyada yaşamaları, dışardan gelen etki ve müdahalelerin bugüne kıyasla 
sınırlı olması ve fikhî çözümlerin büyük oranda Müslümanların iç dinamikleri tarafından oluşturulmasıdır. "Murâbaha akdi” veya "modern murâbaha” tabiri ile İslâm Dünyası̉nda faizsiz bankaların kuruluş yıllarından bu yana yoğun bir şekilde uygulanmakta olan murâbaha li’l-âmir bişs-şirâ (mürekkeb murâbaha) adlı akit ${ }^{1}$ kastedilmektedir. "Klasik murâbaha" tabiri ile fikıh kitaplarında karşımıza çıkan ve klasik fikıhta 'güven akitleri' içinde yer aldığ şekliyle iki taraftan oluşan kârlı satış; "üçlü murâbaha" ile ise İmam Şâfî̀nnin (ö. 204/820) bir ibaresinden hareketle gündeme alınıp dönüştürülen ve modern murâbahaya kaynaklık

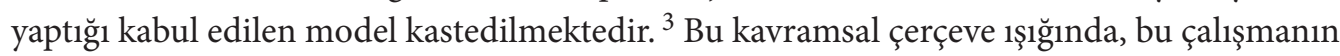
kapsamı yaklaşık kırk yıldır uygulanmakta olan modern murâbaha akdi bağlamındaki fıkhî yaklaşım ve değerlendirmelerin klasik fikıhla (ve özelde klasik fikıhta yer alan murâbaha türleri ile) ilişkisi ile sınırlıdır.

Çalışmanın ana sorusu; "Modern murâbaha akdinin oluşum ve gelişiminde ortaya çıkan hükümlerin üretim sürecinde, klasik fikıh mirası ile sağlıklı ve tutarlı bir ilişki biçiminin varlığından söz edilebilir mi?” sorusudur. Bu ana sorunun cevaplandırılmasına yardımcı olacak önemli alt sorular ise şu şekildedir: Murâbahayı ele alan müelliflerin klasik fikha yaklaşımları nasıldır? Murâbahanın klasik fikıhtaki halinden bugünkü formata gelinceye kadar geçirdiği değişimin arka planı nedir ve bu süreçte hangi araçlar kullanılmıştır? Klasik fıkıhla ilişki açısından murâbaha ile mudârabe ve müşâreke gibi işlemler arasında ortak noktalar var mıdır? Günümüz fakihlerinin klasik fikıhla ilişkisini etkileyen faktörler nelerdir? Bir akdin oluşturulmasında veya eski bir akdin revize edilmesinde günümüz fakihleri nasıl akıl yürütmektedir? Fıkhî çıkarımlarda klasik fikıhla modern fikıh arasındaki farklılaşma noktaları nelerdir? Fıkıh mirası ile ilişkiler açısından farklı ekollerden bahsedilebilir mi? Fıkıh mirasından iktibasla yapılan nakil ve çıkarımlarda bağlama dikkat edilmekte midir? Modern öncesi işlemler ve kurumlar ile modern dönemdekiler arasında benzerlik ve paralellikler bulmak amacıyla doğrudan

1 Faizsiz bankacılıkta en çok başvurulan yöntem olan modern murâbaha (murâbaha li’l-âmir bişs-şirâ) akdinde müşteri genelde nakit yetersizliği sebebi ile kuruma, bir malı alması ve vadeli olarak kendisine satması talebi ile başvurur. Talep olumlu bulunursa kurum malı satıcıdan alır ve vadeli olarak müşteriye satar. Murâbaha konusu ürünle ilgili taksitlerin ödenmesiyle işlem sona ermiş olur.

2 Klasik fikıh literatüründe 'güvene dayanan satışlar' (buŷ̂'u'l-emâne) kapsamında ele alınan murâbaha akdi, tevliye (maliyetine satış) ve vadî‘ (zararına satış) ile aynı kategoride değerlendirilmektedir. Murâbaha, satılan malın ilk alış bedelinin ve satıştan elde edilecek kârın müşteriye bildirilmesi itibarıyla müsâvemeden (satış bedelinin, alış fiyatından bahsedilmeden ve pazarlıkla belirlendiği satış türü) farklıdır. Bu özelliği sebebiyle murâbaha 'mutlak bey' akdinden farklı olarak kendine has şartlar taşır. Klasik murâbaha için نقل ما ملكه بالعقد "الاول بالثمن الاول مع زيادة ربح" (Ebü’l-Hasan Burhaneddin Ali b. Ebî Bekir el-Merginânî, el-Hidâye şerhu Bidâyetü’lmübtedî [nşr. Muhammed Muhammed Tamir - Hafız Aşur Hafı], Kahire: Dârü’s-selam, 2000, III, 995) ve vبيع ما ملكه بما قام عليه و بفضل (Muhammed Emin b. Ömer b. Abdülazîz ed-Dımeşkî İbn Âbidin, Reddü'l-muhtâr ale’dDürri'l-muhtâr şerhu Tenvîri'l-ebsâr Hâşiyetu İbn Abidin (nşr. Âdil Ahmed Abdülmevcûd - Ali Muhammed Muavvaz), Riyad: Dâru âlemi'l-kütüb, 1423/2003, s. 349-350) tarifleri örnek olarak zikredilebilir. Klasik murâbaha akdinin pek çok klasik fıkıh kitabında ayrıntılarıyla ele alındığı görülmektedir (Ayrıntılı bilgi için bk. İsmail Cebeci, Modern İslâm İktisadı Literatüründe Murâbaha Tartışmaları [doktora tezi, 2010], Marmara Üniversitesi Sosyal Bilimler Enstitüsü, s. 28-33).

3 Fıkıh kitaplarında genellikle rastlanan ve iki taraftan oluşan klasik murâbahadan farklı özellikler taşıyan bu model, alıcı ve satıcı dışında, doğal olarak malın satın alınacağı üçüncü bir taraftan bahsetmesi sebebiyle bu çalışmada “üçlü murâbaha” olarak isimlendirilmiştir. Bu modelin ayrıntıları aşağıda zikredilmektedir. 
karşılaştırmalar yapmak ne kadar sağlıklı bir yaklaşımdır? Bu çalışma kapsamında bu sorulara mümkün olduğunca ana hedeften ayrılmadan cevaplar aranacaktır.

Çalışmanın hedeflerine ulaşmak ve belirlenen soruların cevaplarını bulmak için klasik fikıhla ilişkiler bağlamında, müelliflerin hem genel olarak murâbahaya yaklaşımları hem de "vaad", "kabz", "risk" ve "vekalet" gibi murâbahayı oluşturan konuları değerlendirme tarzları incelenecek ve bu yolla fakihlerin konu özelindeki yaklaşımları analiz edilecektir. Bu bağlamda, murâbahayı ele alan ve ayrıca klasik fikıhla ilişki şeklini irdeleyen ve murâbahayı fikhî açıdan değerlendiren önemli eserler bu çalışmanın temel hareket noktasını oluşturmaktadır.

$\mathrm{Bu}$ çalışmaya ilham veren ve kaynaklık eden önemli eserler arasında Yusuf el-Kardavînin Bey'u'l-murâbaha li'l-âmir bişs-şirâ kemâ tücrîhi'l-mesârifüll-İslâmiyye adlı eseri, Abdünnâsır Ebü'l-Besal'in "Menhecü'l-fetvâ fi'l-ahkâmi'l-muâsıra" başlıklı makalesi; İsmail Cebeci'nin Modern İslâm İktisadı Literatüründe Murâbaha Tartışmaları başlıklı doktora tezi ve "Change in the Practice of Ijtihad: The Case of Islamic Finance" adlı makalesi; Soner Duman'ın "Günümüz Fıkhî-İktisadî Problemlerin Değerlendirilmesinde Fıkıh Mirasımız ile İlişki Biçimimiz" isimli makalesi ve Kilian Bälz’nn, Sharia Risk? How Islamic Finance Has Transformed Islamic Contract Law başlıklı çalışmasını özellikle zikretmek gerekir.

Faizsiz bankacılık sisteminde kullanılan murâbahanın 1970'li yıllarda ortaya çıkışından bugüne kadar murâbaha ile ilgili olarak farklı dillerde çok sayıda çalışma yapılmış ve zengin bir literatür oluşmuştur. Ne var ki bu eserlerin çoğu murâbaha akdinin cevaz boyutu ve uygulama esasları üzerine odaklanmaktadır. Bu akdin oluşum ve gelişiminin ardındaki mantıksal bakış açısını analiz etmeye yönelik eserlerin sayısı sınırlıdır. Özellikle murâbaha akdinin doğrudan klasik fıkıh mirası ile ilişkisini anlamaya yönelik yeterli sayıda nitelikli çalışmanın olmaması bu çalışmanın ortaya çıkışının temel sebebini oluşturmuştur.

Aşağıda ilk olarak murâbahanın süreç ve yapı bağlamında klasik fikıhla ilişkisine değinilecek, sonrasında murâbahanın modernize edilmesi sürecinde fakihlerin zihin dünyaları ve klasik fikha yaklaşım tarzları üzerinde durulacaktır. Akabinde klasik delillerin murâbaha bağlamında kullanılma usulü ve çağdaş fakihlerin mezhep algısının konuya etkisi ele alınacaktır. Ardından murâbaha akdine modern yaklaşımlar bağlamında klasik fikıh mirasının yeri ile ilgili birtakım somut tespit ve çıarımlara yer verilecektir. Sonuç bölümünde ise genel olarak f1kıh mirası ile sağlıklı bir ilişki kurulabilmesi için dikkat edilecek hususlar tartışılacaktır.

\section{Süreç ve Yapı Bağlamında Murâbahanın Klasik Fıkıhla İliş̧kisi}

Modern faizsiz bankacilık fikri 1970'lerde hayata geçirildiğinde mudârabe ve müşâreke gibi ortaklık temelli klasik akitler teorik zemin ve tarihi tecrübe açısından ön plana çıkmakta idi. Ancak değişen sosyo-ekonomik şartlar sonucunda, bu tarz akitlerin pratiğe yansitılması ile ilgili bazı zorluk ve problemlerin olduğu çok geçmeden fark edildi. Fıkhî prensiplere 
uygun, reel piyasada uygulanabilir ve faizli bankacılık sistemi ile rekabet edebilecek çözüm yolu arayışları içinde pek çok kaynağa başvuruldu. Bu arayış süreci içinde doğal olarak klasik fıkıh metinleri de temel başvuru kaynakları olarak önemli bir yer tutmakta idi.

Bu çözüm arayışı sürecinde Mısırda, Senhurînin talebesi olan Sami Hasan Hammûd, 1976'da doktora çalışması esnasında, İmam Şâfiî̀nin önemli fürû fikıh eseri el-Ümm'de -ikili klasik murâbaha dışında- çıkış yolu olabilecek bir modele rastladığını belirtti ve mezkûr metindeki "Bir adam başka bir adama malı gösterse ve "Bunu satın al, ben de senden şu kadar kârla satın alayım” dese, o adam da alsa bu alım caizdir..." ibaresine ${ }^{4}$ dikkat çekti. Müşterinin talebi üzerine, murâbıhın (işlemde kâr edecek olan satıcının) talep esnasında elinde olmayan bir malı satın alıp belirli bir kârla müşteriye satması şeklinde de ele alınan bu modelden hareket eden Hammûd, murâbaha li'l-âmir bişşsirâ adıyla yeni bir model uygulamayı teklif etti. ${ }^{5}$ Üç taraftan oluşan bu işlem, faizsiz finansman aracı olarak kullanılan modelin temelini oluşturdu. Bu yaklaşımıyla Hammûd faizli bankaların kambiyo işlemlerine karşı ve müşâreke (sermaye ortaklığı) ve mudârabeden (sermaye-emek ortaklığı) daha geniş ve günün ihtiyaçlarını karşlamada daha etkin bir işlem olarak murâbahayı -yeni şekliyle- pratik bir çözüm olarak ele almış oldu. ${ }^{6}$

Yeni bir akit ortaya koyma tarzına yönelik bu örnekte, iktisadî bir tıkanıklık ve pratik bir ihtiyaç karşısında, klasik bir fikıh metninde bulunan istisnaî bir modelin hareket noktası olarak kabul edildiği, pek çok unsurunun revize edildiği ve faizsiz bankacılık sisteminde (özel bir bağlamda) uygulandığı görülmektedir. Klasik fikıhla ilişkinin niteliği hakkında fikir veren böyle bir uygulama ile ilgili şu üç soru akla gelmektedir:

Birinci soru, "Neden murâbaha akdi veya başka bir akit tamamıyla klasik fikıhtaki şekliyle kullanılmadı?” sorusudur. Bu hususta zaman, şartlar ve ihtiyaçlar gibi pek çok unsurun değişmesi sonucunda murâbaha akdinin klasik formunun, bugünün pratik şartları ve özellikle finans sistemi içinde uygulanmasının zor ve sonuçları açısından verimsiz olduğu düşüncesinin

4 İmam Şâfî̀nin ibaresi şu şekildedir: "Bir adam başka bir adama malı gösterse ve "Bunu satın al, ben de senden şu kadar kârla satın alayım” dese, o adam da alsa bu alım caizdir. Ancak senden kârla satın alayım diyen kiși- satın alıp almama konusunda- muhayyerdir. Yine aynı şekilde "Benim için bir mal al" deyip tarif etse, ya da "istediğin bir mal” deyip kârla satın alacağını söylese hepsinde durum aynıdır. İlk satım caizdir. Bu noktada alıcı muhayyer olup 'peşin veya veresiye alırım' demesi, durumu değiştirmez. İlk satım caiz olur, ikinci satım konusunda ise taraflar muhayyer olurlar. İlk durum kendilerini bağlayıcı olacak şekilde anlaşırlarsa bunun, iki şeyden ötürü feshedilmesi gerekir: Birincisi. Satıcı henüz mala malik olmadan alım satım yapmışlardır. İkincisi. 'Şu kadara satın alırsan şu kadar kâr vereceğim' (demek), muhâtara üzerine anlaşmadır” (Ebû Abdullah Muhammed b. İdris eş-Şâfiî,, Kitâbüll-Ümm - Mevsûatü'l-İmam eş-Şâfî̀ [nşr. Ali Muhammed - Âdil Ahmed], Beyrut: Dâru ihyâi't-türasi'l-arabî, 2001/1422, III, 348). Murâbahanın benzer bir kullanımı için ayrıca bk. Ebû Abdillâh Muhammed b. Hasan b. Ferkad eş-Şeybânî, el-Mehâric fi'l-hiyel, Kahire: Mektebetü's-Sekâfetid-Diniyye, ts., s. 127-8 (Bu eserin İmam Muhammed’e aidiyeti tartışmaları ile ilgili ayrıca bk. Mehmet Boynukalın, İmam Muhammed b. Hasan eş-Şeybânînin Kitâbü’l-Asl Adlı Eserinin Tanıtımı ve Fıkıh Usulü Açısından Tahlili, İstanbul: Ocak Yayınları, 2009. s, 69-70).

5 Modern murâbahanın Sami Hammûd tarafından ortaya atıldığı, araştırmacılar arasında genel bir kabuldür (bk. Feyyaz Abdülmün'im Haseneyn, Bey'u'l-murâbaha fi'l-mesârifi'l-İslâmiyye, Kahire: el-Ma'hedü’l-âlemî li'lfikri'l-İslâmî, 1996, s. 21).

6 Sami Hasan Hammûd, Tatvîru'l-a'mâli'l-masrafiyye bimâ yettefiku veşsşerîate'l-İslâmiyye (doktora tezi, 1976), Kahire Üniversitesi, s. 476-483; Ayrıca bk. Cebeci, Murâbaha Tartışmaları, s. 22, 34. 
etkili olduğu ifade edilebilir. Dolayısıyla modern murâbaha akdine, klasik fikıhtaki bir akdin değiştirilerek günün şartlarına adapte edilmesiyle ulaşlmıştır. Bu da günümüz fakihlerinin zihninde böyle bir dönüştürmenin mümkün olduğuna bir işaret olarak değerlendirilebilir.

Modern murâbahanın klasik fikıhtan revize edilerek üretilme şekliyle ilgili ikinci soru, yeni ihtiyaçlar karşısında yeni bir akde ihtiyaç duyulduğunda "ibâha prensibi"ne rağmen neden yeni baştan bir akit üretilmediği, var olan klasik bir akit üzerinden hareket edildiği ve klasik fikıhtaki "isimli akitler" mantığının terkedilmediği sorusudur. Bu durum şu üç sebeple açıklanabilir:

Meşruiyet arayışı ve klasik fikhın ve fakihlerin itibarı: Herhangi bir işlemi ele alırken literatürde var olan akitlere (özellikle "isimli akitler"e) dayanmak ve bu akit isimlerini bir şekilde kullanmak, ayrıca klasik fıkhın itibarlı simalarına atıf yapmak ve onların görüşlerinden bahsetmek, ortaya çıkan yeni işlemin meşruiyet zemini açısından daha güvenilir bir yol olarak görünmektedir. Bu durum aynı zamanda klasik fikhın hem araştırmacılar ve hem de kamuoyu nezdinde güçlü bir itibarının olduğuna işarettir.

Klasik fikıhtaki bir akit üzerinden hareket etmenin daha pratik ve kolay olması: Klasik fıkıhtan hareketle ele alınan bir akit üzerinde hâl-i hazırda pek çok tartışma yapılmış ve bir altyapı oluşmuş olması ihtimali daha yüksektir. Bu ise tamamen yeni bir akit üretmeye göre daha pratik bir imkan sağlar.

Alışkanlık: Klasik fikhın kavram ve konuları netleştikten sonraki uzun yüzyıllar içinde üretim-tüketim biçimini toptan değiştirecek köklü değişimler çok fazla yaşanmadı̆̆ için Müslümanların yeni akitler üretmeye pek ihtiyaç hissetmedikleri görülür. Bu alışkanlığın, yeni bir akit üretmek yerine doğrudan klasik akitlere atıf yapma konusunda etkisi olabilir. ${ }^{7}$ $\mathrm{Bu}$ üç sebebin murâbaha dışındaki diğer iktisadî işlemlerin oluşma şeklinde de etkili olduğu ifade edilebilir.

Murâbahanın revize edilme sürecine ilişkin üçüncü soru, klasik bir kaynaktan hareketle ortaya atılan bir akdin ne şekilde değiştirildiği, yani klasik murâbahadan modern murâbahaya giden süreçte klasik ve (İmam Şâfiînnin ele aldığı şekliyle) üçlü murâbaha ile modern murâbaha arasında ne tür farklılaşmaların ortaya çıktığı ve ayrıca murâbaha akdinin hangi özelliklerinin devre dışı bırakılarak modern murâbahaya hangi yeni unsurların eklendiğidir. ${ }^{8}$

7 Bu sebeplerin faizsiz finans alanındaki ictihad faaliyeti için de benzer bir yönde olduğu görüşü için bk. İsmail Cebeci, "Change in the Practice of Ijtihad: The Case of Islamic Finance", Ilahiyat Studies, 2012, III, sy. 2, s. 153.

8 Bu noktadaki ilginç tartışmalardan birisi modern murâbahanın eski veya yeni bir akit olması ve bunun sonuçları üzerinde cereyan etmektedir. Örneğin Refik Yunus el-Mısrî modern murâbahanın eskiden beri var olan bir işlem olduğunu, ancak bazı araştırmacıların ya bilmediklerinden ya da -bazı hükümleri değiştirmek amacıyla- işlerine öyle geldi ği için modern murâbahayı yeni bir işlem olarak kabul ettiklerini ifade eder (“Bey'u'l-murâbaha li'l-âmir biş̧ş̧irâ fi'l-mesârifi'l-İslâmiyye”, Mecelletü Mecma'i'l-fikhi'l-İslâmî, 1988, V, sy. 2, s. 1142-3). Buna karşın, günümüz âlimlerinin temel prensiplere riayet ederek yeni akitler oluşturabileceğine vurgu yapan Ahmed Sâlim Mülhim’e göre modern murâbahanın klasik murâbahaya ilhâk edilmesi ya da yeni bir akit sayılması arasında netice açısından bir fark yoktur. Zira birinci durumda doğrudan "isimli akitler" kapsamında değerlendirilecek olan murâbahanın ikinci durumda meşru bir akit olarak yine aynı niteliği taşıması mümkün 
Klasik fikıh kitaplarında yer alan murâbaha ile faizsiz bankacılık sisteminde uygulanan modern murâbaha arasında şekil ve işlev açısından pek çok fark vardır. İki tür murâbaha arasındaki şeklı̂ farklar şu şekilde özetlenebilir: Klasik murâbaha iki taraflı (alıcı ve satıcı) iken modern murâbahanın üç taraflı (malı talep eden müşteri, malı satmak üzere alan banka ve malın satıcısı) bir işlem olması; klasik murâbahada mal satıcıda hazır iken modern murâbahada malın mevcut ve hazır olmaması; klasik murâbahada vaatleşme yer almazken modern murâbahanın vaatleşme üzerine bina edilmesi; klasik murâbahada icab sahibi genelde satıcı iken modern murâbahada alıcının icab sahibi olması; klasik murâbahada satıcının kendisi için almış olduğu ya da uygun bir fiyata satmak amacıyla aldığı bir mal var iken ve alımı üzerinden bir vakit geçmiş iken modern murâbahada bankanın, malı kendisi için değil müşteri talebi üzerine veya belirli bir müşteriye satmak için almış olması; klasik murâbahada işlemin başında müşteri yok iken modern murâbahada mevcut olması; klasik murâbaha akit meclisindeki tek akitten oluşmakta iken modern murâbahanın iki aşamadan (vaatleşme ve akitleşmeden) oluşması; klasik murâbahada semen (mal bedeli) akit meclisinde belli iken modern murâbahada banka malı almadan ve malın maliyeti tam olarak bilinmeden vaatleşmenin bağlayıcı sayılabilmesi; klasik murâbahada mal sahibi klasik manada tüccar iken modern murâbahada malı alıp satan tarafın genelde banka olması; klasik murâbahada semene (mal bedeli) neyin dahil olduğu ihtilaflı iken modern murâbahada bankaların her türlü masrafı semene eklemeleri; klasik murâbahada satıcı, sattığı mal ve nitelikleri ile doğrudan ilgilenip mal konusunda bilgi sahibi iken modern murâbahada bankanın genelde işleme konu olan malla ilgili çok bilgili olmaması; klasik murâbahada pek çok türde mal murâbaha konusu olabilmekte iken modern murâbaha konusu malın risk, bakım masrafları vb. yönlerden sıkı bir seçime tabi tutulması; klasik murâbahada satıcının mala ilişkin olarak yaptığı boyama, tamir, dikiş vs. masraflar semene eklenirken, modern murâbahada bankanın malı hazır alıp satması ve malda bir değişiklik yapmaması; klasik murâbahada mal, artış gösterme ve çoğalmaya elverişli iken (hayvan ve ağaç gibi) modern murâbahada bankanın böyle bir mesuliyete girmek istememesi ve sadece değişken olmayan mallarda murâbahaya başvurması; klasik murâbahada -malın elde tutulması esnasında mala gelebilecek zararlar veya malın piyasa fiyatının değişmesi gibi- riskler söz konusu iken modern murâbahada alınan tedbirler sonucunda riskin son derece azaltılması; klasik murâbahada kâr; gayret, vakit ve riske girmekten kaynaklanırken modern murâbahada kârın kaynağının vade olduğu eleştirisinin getirilmesi; klasik murâbaha peşin ya da vadeli olabilirken modern murâbahanın genelde vadeli ve taksitli olması; modern murâbahada müşteri, murâbaha akdinden önce malın özelliklerini ve fiyatını bilmekte olduğu için -güvenilecek tek merciin satıcı olduğu- klasik murâbahaya göre karşı tarafa yanlış bilgi verme ihtimalinin daha az olması. ${ }^{9}$

olacaktır (Bey'u'l-murâbaha ve tatbikâtühü fi'l-mesârifi'l-İslâmiyye, Amman: Dâru’s-sekâfe, 2005, s. 18).

9 Abdülazîm Ebû Zeyd, Bey'u'l-murâbaha ve tatbîktatbîktatbîkâtühü'l-muâstra fi'l-mesârifi'l-İslâmiyye, Şam: Dâru'l-fikr, 2004, s. 90-1; İzzeddin Hûce, ed-Delîlüşs-şerî̀ li'l-murâbaha (tsh. Abdüssettâr Ebû Gudde), Cidde: Mecmû́atü Delleh el-Bereke, 1998, s. 42; Cebeci, Murâbaha Tartışmaları, s. 36-8. 
$\mathrm{Bu}$ şeklî farkların yanı sıra iki işlem arasındaki işlevsel farklar da önemlidir. Yapı ve işleyiş olarak normal bir bey' akdinden çok farklı olmayan klasik murâbahanın pek çok değişim geçirerek bir finansman akdine dönüşmesi bu iki akdin hedefinin de farklılaştığını ortaya koymaktadır. Bazı klasik kaynaklarda ikili murâbahanın amacının daha ziyade tüccarın tecrübesinden faydalanma ve müşteriyi koruma ${ }^{10}$ hedefi olduğu belirtilir. Buna karşın modern murâbahada müşterinin amacı malın bedelini vadeli olarak ödemek; bankanın amacı ise vadeli satıştan kâr elde etmektir. Bu farklllıklarla birlikte klasik ve modern murâbaha bağlamında tartışılan fikhî meseleler de farklılaşmış, ayrıca iktisadî, kanunî ve idarî unsurlar da modern murâbaha tartışmalarının bir parçası haline gelmiştir. Dolayısıyla her iki tür murâbaha arasında tartışma ve odak noktaları açısından ciddi değişimler söz konudur. ${ }^{11}$

Modern murâbahaya her ne kadar İmam Şafiînnin ele aldığı üçlü murâbahadan hareketle ulaşılmış olsa da bu iki tür murâbaha arasında da önemli farkların olduğu görülmektedir. Zira, klasik fıkıhta işlemin tarafları, aşamaları ve özellikleri açısından daha basit işlemler söz konusu iken modern fikıh bu açılardan daha karmaşık bir yapıya dönüşmüştür. Diğer yandan, İmam Şâfî̉nnin zikrettiği üçlü murâbaha, modern murâbahaya dönüşürken yeni sosyo-ekonomik ihtiyaçlara ve bankacılık mevzuatına paralel olarak pek çok değişime uğramıştır. Örneğin İmam Şâfiînin zikrettiği şekilde vaat bağlayıcı olmayıp akitler bir bütün halinde değildi, satıcı malı bizzat teslim almaktan kaçınmadığı için işlemde kabz meselesinin özel bir ayrıcalığı yoktu, işlemde vekalete başvurulmayıp satıcı, diğer işlemlerdeki gibi malın riskine katlanmakta idi ve ödeme vadeli olmadığından akdin sona ermesi ile ilgili tartışmalar yoktu. Bütün bu değişimler üçlü murâbahanın modern murâbahaya dönüşmesi sürecinde ortaya çıktı. Ayrıca akdin bir finansman modeli olarak kurumsal bir biçimde çok geniş kitleleri ilgilendirecek şekle dönüşmesi ve bankacılık sistemine uydurularak finansal bir akit haline gelmesi bu süreçte gerçekleşti.

Bu bağlamda, modern murâbahayı oluşturan işlemlerin klasik fikha göre nasıl değiştiği ve yeni özelliklerin nasıl eklemlendiği hususunda şunlar söylenebilir: Murâbaha bağlamında klasik fıkıhla irtibatlandırılarak tartışılan en önemli konulardan biri murâbaha işleminde vaadin kazaen bağlayıcı olup olmadığıdır. Bugünkü modelin temeli olarak görülen İmam Şâfiînnin mezkûr metninde alım-satıma dair vaadin bağlayıcı olmadığı ve muhayyerliğe vurgu yapıldığı görülür. Ayrıca Hanefî, Şâfiî, Hanbelî ve Zâhirîler ile bazı Mâlikîlere göre vaade vefa göstermenin müstehap olduğu, ancak kazaen bağlayıcı olmadığı ifade edilir. ${ }^{12}$ Oysa modern murâbaha uygulamasında araştırmacıların kahir ekseriyeti vaadin -en azından taraflardan biri için- kazaen bağlayıcı olması gerektiğini ifade ederler. Bu noktada bağlayıcılık meselesi-

10 Kemalüddin Muhammed b. Abdülvâhid b. Abdülhamîd es-Sivâsî el-İskender İbnü’l-Hümâm, Şerhu Fethi'lkadîr, [y.y.], 1389/1970, VI, 497; Fahreddin Osman b. Ali b. Mihcen ez-Zeyla î, Tebyînü’l-hakâik fî̀ şerhi Kenziddekâik, Bulak: el-Matbaatü'l-Kübra'l-Emiriyye, 1314, IV, 73.

11 Modern murâbaha ile klasik (ikili) murâbaha arasındaki şeklî ve işlevsel farklar için bk. Cebeci, Murâbaha Tartışmaları, s. 36-40.

12 Atıye Seyyid Feyyaz, et-Tatbîkâtü̉l-masrafiyye li-bey'i'l-murâbaha fî dav'i'l-fikhi'l-İslâmî, Kahire: Dârün-Neşr li'l-Câmiât, 1419/1999, s. 74. 
nin bu akitten ve örnekten bağımsız olarak ele alındığı ve hatta prensip olarak murâbahaya mesafeli yaklaşan Mâlikî mezhebine (ve Hanefî mezhebindeki muallak vaade) istinaden vaadin bağlayıcı olduğu ifade edilmektedir. ${ }^{13}$ Ayrıca Ömer b. Abdülaziz (ö. 101/720), İbn Şübrüme (ö. 144/761), İshak b. Râhûye (ö. 238/853) ve sahabe ve tabiûndan bazı isimlere istinaden vaadin mutlak surette (diyaneten ve kazaen) bağlayıcı (mülzim) kabul edildiği ifade edilir.

Vaadin bağlayıcı olduğu hükmüne ulaşma usulü, klasik fikha (hem mezhep içi hem de mezhep dışı kaynaklara) yaklaşımın mahiyeti hakkında da fikir vermektedir ki bu mesele ileride ele alınacaktır. Vaadin bağlayıcılığı kanaatinin oluşmasında, akitlerin yapısının değişmesi ve pratik, güncel ve sosyo-ekonomik ihtiyaçların etkili olduğu görülmektedir. Bu da pratik etkenlerin klasik fikha bakış üzerindeki etkisine bir işaret olarak değerlendirilebilir. ${ }^{14}$

Murâbaha bağlamında klasik fikıhla ilişkiler açısından dikkat çeken diğer bir konu vekalet konusudur. Zira vekalet akdinin modern murâbahada nasıl kullanıldığı da klasik fikha yaklaşım açısından önemli bir örnektir. Klasik fikıh literatüründe ayrıntılı olarak yer verilen ve müstakil bir çerçevede ele alınan vekalet akdinin modern iktisat ve dönüşen akitler içinde yeni bir anlam ve boyut kazanması söz konusudur. İlke olarak modern murâbaha akdi içinde vekaletin yer almasını kabul edenler daha ziyade klasik fikıhtaki vekalet konusuna atıf yaparak vekilin asil gibi olduğunu ve müvekkilinin emrine göre hareket edeceğini ifade etmektedirler. Dolayısıyla vekalet akdinin yeni bağlamına değinmemekte ve müstakil olarak caiz olan vekalet akdinin murâbaha akdi için de geçerli olmasında bir sakınca görmemektedirler. Vekalet akdinin modern murâbahada kullanılması, klasik fikıhta geçerli olan bir akdin başka -ve özellikle birden çok aşamalı ve yeni- bir işlem içinde kullanılması durumunda hükmün aynı kalması ya da değişmesi açısından önemli bir örnektir. Bu mesele ile ilgili varılan sonuç diğer benzer durumlara da örneklik teșkil edecektir.

Murâbaha akdinin sahip olduğu yeni şekil sonucunda klasik fikha kıyasla ortaya çıkan diğer önemli değişimler şunlardır: Vaadin bağlayıcı olmasının da etkisiyle bir satış içinde iki satış yasağının gündeme gelmesi, gerçek ve şeklî (hakikî ve hükmî) kabzın etkisinin tartışılması, modern murâbahada bankanın pek çok tedbir alarak risklerin neredeyse tamamını müşterinin üzerine devretmesi, müşterinin bankanın vekili olması ve bunun sonucunda

13 Örneğin 1979'da Dubai'de yapılan Birinci İslâm Bankacılı̆̆ı Kongresinde, 59 âlim tarafından Mâlikî mezhebine istinaden vaadin bağlayıcılığının geçerliliğini savunan görüş benimsenmiştir.

14 Cebeci akitlerde vaad unsurunun kullanılmasını şu şekilde ifade etmektedir: "Vaadin bu kadar etkin bir hale gelerek pek çok işlemi ilgilendirmesi, iktisadî işlemlerin yeni beklentilere cevap vermek için kullanılmasının bir sonucu olarak akit türlerinin değişmesi ve gelecek zaman faktörünün ciddi bir biçimde akitlerin içinde yer almasıyla olmuştur. Bilindiği üzere normal şartlarda bir akit derhal ve kesin bir şekilde tamamlanır ve sonuç doğurur. Mesela taraflar normal bir bey' (satım) akdi yapınca akit tamamlanır. Satıcı parayı, müşteri de malı almaya hak kazanır. Bu durumda vaade ihtiyaç duyulmaz ve vaad işlemin bir unsuru olarak görülmez. Oysa modern dönemde kullanılan pek çok akit, işlemin atfedildiği zaman dilimi, işlemin kesinliği ve içerdiği merhaleler açısından farklı özellikler taşımaktadır. Bu durumda akdin gelecek zamana izafe edilmesinin ya da tam olarak kesinleşmesinin, akdin taraflarından birinin ya da her ikisinin bazı yükümlülükleri yerine getirmesi şartına bağlanması, vaad unsurunu işlemlerin önemli bir parçası haline getirmiştir” (Murâbaha Tartışmaları, s. 68). 
ortaya çıkan damân (malla ilgili yükümlülük) ve şeklîlik tartışmaları ve işlem genelde vadeli olarak gerçekleştiği için zamanında yapılmayan ödeme ile ilgili tartışmalar klasik fikıh kitaplarında murâbaha konusu içinde yer almayıp yeni ortaya çıkan özelliklerdir.

\section{Murâbahanın Modernize Edilmesi Sürecinde Fakihlerin Zihin Dünyaları ve Klasik Fıkha Yaklaşım Tarzları}

Bu bölümde, murâbahaya ilişkin olarak yukarıda belirtilen değişimlerin nasıl bir bakış açısıyla ve ne tür yaklaşımlarla yapıldığı ele alınacaktır. Başka bir deyişle fürû alanında ortaya çıkan değişimlerin usûlî ve mantıksal arka planı ortaya koyulacak ve temel olarak klasik fikha yaklaşımlarda zaruret-maslahat ve sedd-i zerâi ${ }^{15}$ düşüncesinin etkisi üzerinde durulacaktır. Literatürde murâbaha bağlamında klasik fıkha farklı bakış açıları bulunmakla birlikte şu iki temel yaklaşımdan bahsedilebilir.

\subsection{Klasik Fıkha Zaruret ve Maslahat Temelli Yaklaşım}

Bu yaklaşım, meseleleri sadece fikhî olmanın ötesinde değerlendiren, İslâmî bir hayat ve Müslümanların maslahatı için işleyen bir iktisat ve bankacılık sisteminin varlığını zarurî gören ve bu doğrultuda mevcut naslar için farklı yorumlar arayan, ihtiyaç halinde şimdiye kadar pek itibar edilmemiş görüşleri ön plana çıkaran, farklı mezhepler arasında tercihler yapan ve bazı durumlarda zamanın ihtiyaç ve zaruretlerinin bir sonucu olarak ictihad yoluna başvuran ve kolaylık ilkesine vurgu yapan yaklaşım olarak tanımlanabilir. ${ }^{16}$

Zaruret ve maslahat düşüncesi, günümüzde fikhî hüküm üretme faaliyetlerinde ve konumuz olan murâbahada önemli hareket noktalarından biridir. ${ }^{17} \mathrm{Bu}$ tür bir yaklaşıma ağırlık verenler, temel olarak ibâha (mubahlık prensibi) ve teysire (kolaylık) vurgu yapmaktadır. Zaruret düşüncesinin -açlk ya da gizli olarak- hem genel olarak murâbaha fikrinin ortaya atılmasında ve sürdürülmesinde hem de murâbahanın alt konularında yapılan çıarımlarda etkili olduğu görülmektedir. Gayri İslâmî bir iktisat ve bankacılık sistemi içerisinde İslâmî hükümlere uygun bir işlem yapma hedefinin varlığı ve bu surette sistemin ayakta tutulmasının hedeflenmesi, genel anlamda zihinsel bir zaruret düşüncesinin bulunduğuna işaret olarak değerlendirilebilir. Bunun yanı sıra murâbaha bağlamında klasik fıkıhla irtibat kurarken zaruret düşüncesini doğuran mevcut bazı zorluk ve zorunluluklar bulunmaktadır. Bunların önemlileri şöyledir: Kanunî zorunluluklar, piyasa şartları ve iktisadî zorunluluklar, modern

15 Bu kavramlar ve İslâmi finans alanındaki bazı yanlış kullanımları için bk. Abdulazeem Abozaid, "Role of Fiqh in Islamic Finance”, İslâm İktisadı Atölyesi-1: Temel Kavramlar ve Fikirleri 2-3 Mart, Istanbul-Türkiye, y.y, t.y, s. $40-42,45-48,50$. Cebeci, Murâbaha Tartışmaları, s. 187.

17 Bu bağlamda, "Meşakkat teysiri celbeder" (Mecelle, 17. madde); "İş daraldığında genişler" (Mecelle, 18. madde); "Zaruretler memnu olan şeyleri mubah kılar” (Mecelle, 21. madde) kaidelerinin kullanıldığı ve bunların açıkça zikredilmese de pek çok hükme temel teşkil ettiği görülmektedir. 
ticarî örf faktörü, kurumsal yapıdan kaynaklanan zorunluluklar, bankacilık sisteminden ve müşterilerden kaynaklanan zorluklar. ${ }^{18}$ Problemleri çözme gayreti içinde olan araştırmacıların, bu engellerle karşılaşılması durumunda zaruret çerçevesinde hüküm vermeleri ve bu anlayışın klasik fikha yansıması yaygın bir durum olarak görünmektedir. Murâbaha konusunda da benzer bir halden söz edilebilir.

\subsection{Klasik Fıkha Sedd-i Zerâi‘ Temelli Yaklaşım}

Modern İslâm iktisadında pek çok meselede olduğu gibi modern murâbaha akdi ile ilgili çıkarımlarda da sedd-i zerâi ' prensibiyle hareket eden bir yaklaşımın varlığı dikkat çekmektedir. ${ }^{19} \mathrm{Bu}$ tür bir yaklaşımı benimseyenlerin klasik literatürdeki temel görüşlere daha çok bağlı ve naslarda belirtilen unsurları ve kabul edilegelen yorumları olduğu gibi kabul etmeye daha fazla yatkın olduğu ve zaruret ve maslahat temelli çıarımlarda bulunma konusunda daha çekingen oldukları görülmektedir.

$\mathrm{Bu}$ şekilde düşünenler, pratikten hareket ederek zaruret ve maslahat düşüncesi ile hüküm üretenlerin bulduğu çözümlerin -bazen başlı başına caiz olsa da- tehlikeli bir noktada bulunması ve özellikle faize götüren sakıncalı işlemler için kullanılmaya son derece müsait olması sebebiyle caiz kabul edilmemesinin daha uygun olacağı kanaatindedirler. ${ }^{20} \mathrm{Bu}$ bağlamda ortaya atılan düşünceler, ilk bakışta çok dar gibi görünse de, birtakım endişe ve hassasiyetlerin varlı̆̆ını sürdürmesi bakımından önemlidir.

Murâbaha tartışmalarında bu iki farklı ekolün klasik fikha yaklaşımını tespit sadedinde Yusuf el-Kardâvî ve Refik el-Mısrî arasındaki tartışma ufuk açıcıdır. Murâbaha literatürü içinde en etkili ve tartışmaların yönünü belirleyen şahıslardan biri Kardâvî olmuştur. Ağırlıklı olarak zaruret ve maslahat düşüncesiyle hareket eden Kardâvî klasik fikha yaklaşım konusunda da bazı temel prensipler ortaya koymuş ve klasik fıkıh içindeki değişime ve farklı örneklere dikkat çekmiştir. Kardâvînin tespitleri murâbaha bağlamında klasik fikha yaklaşım açısından da çok önemlidir. Murâbahayı ele alırken klasik fıkıhta belirtilen her hükmün doğrudan nakledilmesine karşı çıkan Kardâvî, modern muamelelerin helal olduğuna dair kavil aramanın hatalı olduğunu ifade ederek her yeni meseleye geçmişten (klasik fikıhtan) bir tahric ya da hüküm arayanları eleştirerek değişim ve ictihada vurgu yapmaktadır. Meselelerin köklerine inmeye çalıştığını, mezheplerin kavillerini olduğu gibi almadığını, bu kavilleri ve delillerini tartıştı̆̆ını ifade eden Kardâvî zaman zaman istisnâc, ${ }^{21}$ cuâle, hayvanla-

18 Ayrıntılı bir değerlendirme için bk. Cebeci, Murâbaha Tartışmaları, s. 189-95.

19 Murâbaha bağlamında sedd-i zerâi' ile ilgili olarak bk. Abdülazîm Ebû Zeyd, Bey'u'l-murâbaha, s. 181-201; Ayrıca bk. Cebeci, Murâbaha Tartışmaları, s. 199-202.

20 Cebeci, Murâbaha Tartışmaları, s. 187, 199.

21 Zira Ebû Hanîfe (ö. 150/767) istisnâ‘ akdinde taraflara muhayyerlik tanırken Ebû Yusuf (ö. 182/798) insanların ahlakındaki değişmeden hareketle ve zamanın şartlarına daha uygun olması sebebiyle esnafı zarardan korumak için, şartlarına uyulduğu takdirde taraflara muhayyerlik tanımamaktadır. Mecelle-i Ahkâm-ı Adliyye de zamanın maslahatına daha uygun olması sebebiyle Ebû Yusuf'un görüşünü benimsemiştir. Ayrıca bk. Ali Haydar, Dürerü'l-hükkâm şerhu Mecelleti'l-Ahkâm, İstanbul: Matbaa-i Tevsi-i Tibaat, 1330, I, 659-60. 
rın doyurulması ve zorunlu vasiyet bugün darülharbe giderken mushaf taşıma konusunda problem görülmemesi gibi klasik fikıhtaki değişimlerden kendisine destek olacak örnekler ortaya koymaktadır. ${ }^{22}$

Buna karşın modern murâbaha konusunda şüpheli noktalara dikkat çeken ve uygulamadaki pek çok hususa itiraz eden Refik el-Mısrî, Kardâvîye cevap sadedinde, murâbahada isimlendirmenin doğru olmadığını, vaadin bağlayıcı olmasının -garara götürdüğünden dolayı- caiz olmadığını, telfikin kaide ve sınırları olması gerektiğini, teysir ve ibâha anlayışının kişiyi yanlışa götürebileceğini ifade eder. Ayrıca vaadin bağlayıcı sayıldığı murâbaha akdinin, vaat ve akit olarak iki kısma ayrılmasının sadece akdin başında bey‘ lafzından kaçma anlamına geldiğini ifade eden Mısrî bu şekildeki murâbaha ile hiyel arasında bağlantı kurar ve bağlayıcı murâbahanın, yerine alternatif olarak sunulduğu kıymetli evraktan çok da farklı olmadığı sonucuna varır. Bunun yanı sıra Mısrînin murâbahada vaadin bağlayıcı olmasının hiçbir mezhepte geçerli olmadığını söylemesi ve "bir satış içinde iki satış" gibi meselelerdeki mevcut yorumda ssrar etmesi ve ictihad gibi kavramlardan bahsetmemesi, kendisinin işlemlerde klasik fikıhta ortaya konulmuş akit modellerini takip eden bir yöntem izlediğini gösterir. ${ }^{23}$ Mısrînin kabz ve vekalet gibi konularda yeni şekillere mesafeli durması ve bankanın normal bir tüccar gibi davranmasını istemesi bu kanaati güçlendirmektedir. ${ }^{24}$

Zaruret-maslahat ve sedd-i zerâi temelli bakış açısının hareket noktaları göz önüne alındığında her iki yaklaşımın da dikkate değer fikirlere sahip olduğu ifade edilebilir. Ancak zaruret-maslahat temelli yaklaşımın günümüzde daha baskın olduğu ve pratik işleyişle irtibatlı olarak daha fazla devreye sokulduğu görülmektedir. Bununla birlikte, sedd-i zerâi ${ }^{\prime}$ yaklaşımının endişelerinin de dikkate alınması, denge unsuru açısından önemlidir.

\section{Klasik Delillerin Murâbaha Bağlamında Kullanılma Usulü}

Klasik delillerin murâbaha bağlamında kullanılma usulü ve bu delillere yapılan atıfların niteliği, klasik fıkıh mirası ile ilişki biçimi açısından önemli ipuçları sunmaktadır. Bu bölümde murâbaha akdi bağlamında önemli klasik delillerin nasıl kullanıldığına dair bilgi verilecektir. Sırasıyla murâbaha ile ilgili çıkarımlarda nasların, klasik fikıh kitaplarının ve küllı̂ kaidelerin kullanılma biçimi üzerinde durulacaktır.

22 Yusuf Kardavî, Bey'u'l-murâbaha li'l-âmir biş'şirâ kemâ tücrîhi'l-mesârifü'l-İslâmiyye, Kahire: Mektebetü Vehbe, 1987, s. 20-21, 32, 77, 79-81, 104, 116.

23 Refik Yunus el-Misrî, “Bey'u'l-murâbaha li'l-âmir bi’ş-şirâ kemâ tücrîhi'l-mesârifü’l-İslâmiyye”, Mecelletü'lümme, Muharrem 1406 / Eylül 1985, sy. 61, s. s. 26, 27, 41, 47, 49. 


\subsection{Kur'ân ve Sünnet Naslarının Kullanımı}

Modern murâbaha ile ilgili meselelerde Kurân ve Sünnet’e doğrudan yapılan atıfların son derece sınırlı olduğu görülmektedir. Bu hususta murâbahanın, satım akdinin meşruiyetine dair naslardaki çerçeveden daha geniş bir problem kümesi oluşturması ve konuya ilişkin mesele ve çıkarımların bir akıl yürütmeler bütününün sonucu olması etkilidir. Bunun yerine mezhep ya da müctehidlerin kavillerine atıfların daha çok olduğu görülmektedir. Kurân-1 Kerim naslarına sadece satım akdinin helalliği konusunda atıf yapılmakta, -kabzın keyfiyeti, bir satış içinde iki satış gibi- murâbahanın bazı alt konularında hadislere atıf artmakla birlikte hadislerin kullanımı yine de sınırlı düzeyde kalmaktadır. Sedd-i zerâi ${ }^{\prime}$ yaklaşımı, bazı hadisleri kabul edilegelen yorumuyla ortaya koymakta ve bunlar üzerinden pratikteki uygulamalara itirazlar getirmekte iken zaruret ve maslahat yaklaşımı hadisleri, metin ve senet tenkidine tabi tutup hadislerin çerçevesini değerlendirmek, mevcut farklı yorumları ön plana çıkarmak ya da daha üst veya karmaşık bir işlem için kullanmak yoluna gidebilmektedir. ${ }^{25}$ Örneğin vaadin bağlayıcılığını savunanlar vaatleri yerine getirmeye vurgu yapan bazı âyetlere (örneğin 61/es-Saff: 2-3; 5/el-Mâide: 1; 17/el-İsrâ: 34) ve münafıkların alametlerinden bahseden hadislere atıf yaparken ${ }^{26}$ vaat konusunda muhayyerliği savunanlar ma'dûmun satışı ve bir satış içinde iki satışla ilgili hadisleri ön plana çıkarmaktadır. Vaadin bağlayıcı olduğu görüşünde olanlar ise konu ile ilgili hadisleri farklı şekillerde değerlendirmektedir. ${ }^{27}$

\subsection{Klasik Fıkıh Metinlerinin Kullanımı}

Modern murâbaha literatüründe genelde çalışmaların baş tarafında klasik fikıh kitaplarındaki klasik (ikili) ve üçlü murâbaha modellerine yer verilmekte ancak modern murâbahanın işleyişi ele alınırken klasik murâbahadan bahsedilmemektedir. Diğer taraftan modern murâbaha akdinin parçaları ayrı ayrı değerlendirilip klasik fıkıh kitaplarında ilgili konuya ilişkin kısma ve mezhep görüşlerine atıf yapılmaktadır. Örneğin murâbahada vaat meselesi ele alınırken sadece vaatle ilgili kaynaklara, vekaletle ilgili kısımlarda ilgili bölümlere veya damân konusuna müstakil olarak değinilmekte ve klasik fikıhtaki murâbaha ile irtibat kurulmamaktadır. Bu da akdin bağlamının ihmal edildiğine ve klasik fikha parçalı bir şekilde yaklaşıldığına delil olarak değerlendirilebilir.

\subsection{Küllî Kaidelerin Kullanımı}

Murâbaha ile ilgili çıkarımlarda küllî kaideler çok sık zikredilmemekte, sadece bazı araştırmacılar tarafından zaman zaman görüşlerini desteklemek üzere kullanılmaktadır. Deliller hiyerarşisinde küllî kaideler öncelikli bir konumda olmayıp destek mahiyetinde ele 
alınmaktadır. Umumiyetle genel kapsamlı kaidelere başvurulmakta olup dar kapsamlı kaide ve zabıtaların (belirli bir meseledeki kural) kullanımı daha sınırlıdır.

Doğal olarak maslahat ve zaruret yaklaşımı daha ziyade mubahlık prensibi ve kolaylıkla ilgili kaidelere atıf yaparken, ${ }^{28}$ sedd-i zerâii yaklaşımına ağırlık verenler, şüpheli șeylerden uzak durmak vb. ile ilgili külli kaideleri ön plana çıkarmaktadır. ${ }^{29}$ Bir kısmı çok genel kapsamlı olan bu kaidelerin duruma göre farklı amaçlar için kullanılabileceği ifade edilebilir. Bunların hepsi doğru kabul edilen ve yerine göre bir anlam ifade eden kaideler olmakla birlikte sadece kaide temelli çıkarımlar yapmanın problemler taşıdığını ifade etmek gerekir. Zira farklı görüş sahipleri kendi amaçları doğrultusunda fikhî kaidelere vurgu yapabilirler. Dolayısıyla murâbaha ile ilgili çıkarımlarda küllî kaidelere atıfta bulunmanın çok cüz'̂̀ olarak başvurulan bir yöntem olmasının doğru bir tartışma tekniği olduğu görülmektedir. ${ }^{30}$

\section{Klasik Fıkha Yaklaşımlarda Mezhep Algısının Etkisi}

Günümüz araştırmacılarının mezhep anlayışları modern murâbaha ile ilgili yaklaşımlarını yansıtması açısından büyük bir önemi haizdir. Ortaya konulan çözüm arayışlarında farklı mezhep görüşlerinin bir araya getirilmesi ile oluşmuş yeni hükümlerle karşılaşılmaktadır. Ayrıca hiç bir mezhebin görüşünü temsil etmeyen âlimlere de ihtiyaç halinde atıfta bulunulduğu görülmektedir. Bu itibarla mezhep kaynaklarıyla mezhep dışı kaynaklar ${ }^{31}$ arasında -delil değeri vs. açısından- bir farklılık gözetilmemektedir. Bu da günümüzde özellikle iktisadî alanda belirli bir mezhep bağlamında bir meseleyi değerlendirme ve hüküm üretme çabasının neredeyse ortadan kalkması ve mezhep anlayışının modern öncesi döneme göre farklı bir anlam ifade etmesi olarak değerlendirilebilir.

Murâbaha ile ilgili çıkarımlarda mezheplerin görüşleri, tartışmanın önemli bir dayanak noktasını oluşturmakta ve vaat, kabz, bir satış içinde iki satış, risk ve vekalet gibi konularda mezhep görüşlerine atıf yapılmaktadır. Ancak hüküm üretme çalışmaları esnasında nakledilen mezhep görüşü ile mezhep birikimi arasında genelde ilişki kurulmaz. Mezhep kavilleri farklı görüş mensupları tarafından -ihtiyaç görülen durumlarda- kullanılır ve görüşler nakledilirken genelde hiyerarşik bir düzen gözetilmez. Herhangi bir müctehidin görüşü ile bir mezhep imamının görüşü arasında pek bir fark görülmez ve bu yaklaşıma tartışmanın

28 Kardâvî, Bey'u'l-murâbaha, s. 13-23.

29 Birinci yaklaşım sahipleri, "Muamelatta asıl olan ibâhadır", "Muâmelât, illet ve maslahatların gözetilmesi üzerine mebnidir", "Mevrid-i nas olmayan mevzuda ictihad mümkündür”, "Örfen mâruf olan şey şart kılınmış gibidir" ve "Zarar ve zarara zararla karşılık verme yoktur” gibi külli kaideleri kendilerine destek olarak zikrederlerken ikinci grup içinde yer alanlar, "Şer'e gayr-1 muvâfık her şart fâsiddir", "Şüpheleri terk etmek evlâdır”, "Harama götüren şey haramdır” ve "Külfet nimete ve nimet külfete göredir” gibi külli kaideleri ön plana çıarmaktadır. Cebeci, Murâbaha Tartışmaları, s. 204-6.

31 Murâbaha bağlamında mezhep dışı delillendirmede en fazla atıf yapılan müellifler İbn Teymiye ve İbn Kayyim’dir. Özellikle zaruret ve maslahat yaklaşımı ile hareket edenler, çıkar yol olarak düşündükleri çözümler için mezhep görüşlerinden delil bulamadıkları pek çok durumda bu iki kaynağı çokça kullanmıştır. Vaat, bir anlaşma içinde iki anlaşma, muallak, mukayyed ve muzâf akitlerle ilgili meseleler bunun başlıca örnekleridir (Cebeci, Murâbaha Tartışmaları, s. 208). 
taraflarınca itiraz edilmez. Kaynak değeri olarak mezhepler, sıkı bir şekilde intisab edilmesi gereken ve birbirinden kesin çizgilerle ayrılmış ekoller değil, pek çok fikhî görüşü içeren ve aralarında geçişlerin mümkün olduğu zengin kaynaklar (hukuk mirası) olarak algılanmaktadır. Dolayısıyla bir konuda bir mezhebin görüşüne tâbi olmak ve başka bir konuda farklı bir mezhebin görüşünü nakletmek yaygın bir davranıştır.

Murâbaha ile ilgili çıkarımlarda belirli bir mezhebe bağlı olmaktan ziyade bazı prensipleri öne çıkaran ekollerden bahsedilebilir. Yeri gelince bütün mezheplere atıf yapılmakla birlikte, mezhepler bağlamında süregelen bir tartışmadan bahsetmek mümkün değildir. Literatürde farklı mezhep kaynaklarına atıflar yapılsa da modern murâbahayı değerlendirme noktasında mezhep faktörünün belirleyici bir etkiye sahip olduğunu ifade etmek zordur. Bu sebeple, farklı mezheplere bağlı araştırmacıların belirli bir meselede aynı şekilde düşündügü, bazen da aynı mezhep müntesibi olan şahısların farklı hükümlere ulaştıklarını görmek mümkündür. ${ }^{32}$

Murâbahanın farklı unsurlarında farklı mezhep ve görüşlere atıflar vardır. Murâbahayı üç taraflı şekliyle -vaat bağlayıcı olmaksızın- ilk zikreden İmam Şâfiî̀dir. Vaadin kazaen bağlayıcılı̆̆ında Mâlikî mezhebine, akdin birden fazla aşamadan oluşması ve şartlar meselesinin cevazında Mâlikî ve Hanbelî mezheplerine, kabz meselesinde dört mezhebin tamamına, risk meselesinde Hanefî ve Hanbelî mezheplerine ve vekalet meselesinde Mâlikî ve Hanbelî mezheplerine atıflar bulunmaktadır. Dolayısıyla modern murâbaha pek çok mezhebe atıfla oluşturulmuş bir işlem olma niteliği taşımaktadır. ${ }^{33}$

Murâbaha işleminin vaat, kabz, vekalet gibi pek çok alt konusunda farklı mezheplere ve yeri gelince mezhep dışı kavillere başvurulması telfik konusunu gündeme getirmiştir. ${ }^{34}$ Hâl-i hazırdaki mekanizmaya karşı çıkanlar murâbaha modelinin üretilmesine telfik yoluyla ulaşıldığını söyleyerek bu durumu eleştirirler. Bu görüşe göre, murâbaha modeli, taraflara muhayyerlik tanıyan İmam Şâfî̀’den alınmış olup vaadin bağlayıcılığı hükmü ise bu şekliyle murâbahayı caiz görmeyen Mâlikî mezhebinden nakledilmiştir. Dolayısıyla sakıncalı bir telfik işlemi söz konusudur. ${ }^{35}$ Vaadin bağlayıcılığı hükmüne telfik ile ulaşıldığını iddia edenlere karşı çıkan Yusuf el-Kardâvî ise telfikin, taklid ile ilgili bir durum olduğunu, herhangi bir mesele hakkında istidlâl ve tercihe dayanan fikhî bir görüşün, taklid dairesine girmeyip telfik sayılmadığını ve ayrıca vaat meselesinin murâbaha ile ilgili değil, kendi başına müstakil bir mesele olduğunu ifade etmektedir." 36

32 Murâbaha bağlamında mezhep telakkilerinin değerlendirilmesi için bk. Cebeci, Murâbaha Tartışmaları, s. 206210; Abdünnasır Ebü'l-Besal, "Menhecü'l-fetvâ fi'l-ahkâmi'l-muâsıra” Ebhâsü'l-Yermûk, Haziran 2002, XVIII, sy. 2 B, s. 473 .

Cebeci, Murâbaha Tartışmaları, s. 212.

34 Telfikçi yaklaşımın problemleri için bk. Soner Duman, "Günümüz Fıkhî-İktisadî Problemlerin Değerlendirilmesinde Fıkıh Mirasımız ile İlişki Biçimimiz”, Uluslararası İslâm Ekonomisi ve Finansı Araştırmaları Dergisi, 2015, I, sy. 1, s. 159-163. 


\section{Murâbaha Akdinden Hareketle Klasik Fıkıh Mirası ile İlgili Çıkarımlar}

Çalışmanın başında murâbaha akdinin klasik fıkıh mirası ile kurulan ilişkiyi değerlendirmek için verimli bir alan olduğu ifade edilmişti. İște bu bölümde, şu ana kadar ele alınan konuların ışı̆̆ında, modern murâbaha üzerinde çalışan ve hüküm üreten araştırmacıların klasik fikha yaklaşımları ve klasik fikıh metinleri ile ilişkileri maddeler halinde analiz edilecek, mevcut yaklaşım ve ilişkilerin olumlu ve olumsuz yönleri değerlendirilecektir.

Çağdaş fakihlerin klasik fikha yaklaşım tarzı, sahip oldukları genel fıkıh algısının bir parçası olarak görünmektedir. Eğer bir fakih/araştırmacı pratik problemler karşısında çözüm arayışı içinde ise klasik fıkha bakarken de aynı saikle bakmakta veya genelde zaruret temelinde bir bakış açısına sahipse bu yaklaşım klasik fikha bakışına da yansımaktadır.

Murâbaha literatürü içinde klasik fikha bakışta yeknesak bir anlayıştan bahsetmek isabetli görünmemektedir. Farklı saiklerle hareket edenlerin varlığ söz konusudur. Bunlar içinde klasik fikha zaruret ve maslahat temelli yaklaşımın ağırlıkta olduğu ifade edilebilir. Bunun karşısında yer alan sedd-i zerâi temelli bir yaklaşımdan bahsedilebilir. Birinci yaklaşım nasların ve klasik fikıh metinlerinin muhtemel yorumlarına geniş bir biçimde kapı açarken ikinci yaklaşım sahipleri daha çok metin temelli hareket etmekte, bu haliyle murâbaha ile hiyel arasında bağlantı kurmakta ve murâbahayı bey'u'l-îneye benzetmektedirler. ${ }^{37}$

Farklı yaklaşım sahipleri arasında klasik fıkıhtaki görüşleri farklı değerlendirenler bulunmasına karşın klasik kaynakları tamamıyla yok sayan bir anlayışa rastlanmamaktadır. Bu da klasik fikhın, bakış açısı ne olursa olsun güncel meselelere çözüm arayan araştırmacılar nezdinde önemli bir yere sahip olduğunu göstermektedir.

Pratikten teoriye hareketle hüküm üretme mantığının klasik fikha bakışta da etkili olduğu görülmektedir. Örneğin, murâbahanın sürdürülebilir bir işlem olması için -sosyal ve iktisadi şartlar gereği- vaadin bağlayıcı olması gerektiği veya işlemin birden çok aşamadan oluşmasının zorunlu görülmesi, klasik fikıh kaynaklarına müracaat etmeden önce fakihlerin zihinlerinde önkabul olarak varolan gerçeklerdir. Bu itibarla, pratik ihtiyaçların etkisiyle çözüm arayan fakihler klasik fikha teorik bir doktrin olmaktan ziyade çözümler kümesi olarak bakmaktadır. $\mathrm{Bu}$ noktada, çözüm arayışlarının sadece akademik saiklerle değil, azımsanmayacak bir oranda iş dünyası ve piyasanın yönlendirmesi ile gerçekleştiğini unutmamak gerekir. Konu ile ilgili olarak düzenlenen ilmî toplantı vb. organizasyonların önemli bir kısmının faizsiz bankalar gibi finansal kuruluşlar tarafindan desteklenmesi veya fetva heyetlerinin hatırı sayılır bir bölümünün bu kurumlar bünyesinde çalışması bu duruma bir delil olarak değerlendirilebilir.

Murâbaha ile ilgili çıkarımlarda usul temelli bir bakış açısından ziyade furû temelli bir yaklaşımdan söz edilebilir. Pratikte cereyan eden olayların ve sosyo-ekonomik ihtiyaçlara göre şekillenen uygulamaların belirleyici olduğu söylenebilir.

37 İkinci yaklaşım için örneğin bk. Refik Yunus el-Mırrî, Bey'u'l-murâbaha li'l-âmir bişs-şirâ fi'l-mesârifi'l-İslâmiyye,

Beyrut: Müessetü’r-risâle, 1996, s. 47. 
Modern bağlamda gündeme getirilen pek çok konu ve kavram klasik fikıh çerçevesinde görünmesine rağmen aslında fikhü̈n-nevâzil kapsamındadır. Örneğin murâbaha bağlamında kullanılan vaat, kabz ve vekalet gibi kavramlar klasik fikıhta da yer almalarına karşın bugün çok farklı ve yeni bağlamlarda ve farklı işlemlerin parçası olarak ortaya çıkmaktadır. Dolayısıyla yeni konu ve kavramlarla klasik fikıhtakiler arasında doğrudan özdeşlik kurmak yanıltıcı olabilir.

Murâbaha ve diğer akitler arasında, klasik fikha yaklaşım hususunda ortak bir bakış açısından ve zihniyetten bahsedilebilir. Murâbaha ile mudârabe veya müşâreke gibi diğer bir akit arasında veya farklı bir alandaki bir mesele bağlamında çıkarım yapılırken klasik fıkha benzer şekillerde yaklaşıldığı görülmektedir.

Murâbaha bağlamında fikhın eski kapsamından uzaklaşıldığı ve bir daralma olduğu ifade edilebilir. Buna göre;

Fikıh mantığının daralarak daha sınırlı bir kapsama sahip olan İslâm hukuku sınırlarına çekildiği görülmektedir.

Bütün bir hayatı kuşatan fıkıh mantığından ziyade belirli bir meseleye cevap verme gayreti taşıyan fetva mantığının ağır basması dikkat çekicidir. Yani ilgili meselelerin bütüncül olarak teorik bir zemine oturtulmasından ziyade sadece bir soru-cevap faaliyeti olarak ele alındığı görülmektedir.

Ahlaki değerleri ve buna ilişkin hükümleri içeren fikıh mantığından sadece hukuki kurallar manzumesi olan kanun mantığına geçişin izleri görülmektedir.

Fıkıh mantığından kanun mantığına geçişin bir işareti "caizdir" ve "caiz değildir" hükümleri arasındaki kategorilerin ortadan kalkmasıdır. Buna göre murâbahaya dair verilen hükümlerde müstehab, mekruh gibi ara kategorilerden neredeyse hiç bahsedilmediği görülmektedir. Bu da fıkhın ahlaki yönlerine işaret eden bu ara hükümlerin kalkmasıyla fikhın ayrılmaz bir parçası olan ahlakî hassasiyetlerin etkisizleşmesi ${ }^{38}$ ve fikhın bir hukuki kurallar bütünü olan kanun çerçevesine sıkışması olarak değerlendirilebilir. Fıkıh metinlerinin pür hukuk kaynağı bakış açısıyla ele alınması ve ahlaki yönlere gerektiği kadar önem verilmemesi zorunlu olarak bu sonucu doğurmaktadır. Bu durum aynı zamanda günümüz Müslümanlarının fikhî meselelere yaklaşımına dair önemli ipuçları sunmaktadir.

Flkıh mirası ile ilişkilerde parçalı (atomik/minimalist) düşüncenin etkisi birçok alanda görülmekte olup murâbaha ile ilgili meselelerde de klasik fikıh metinlerinin bütüncül bir bakış açısıyla değerlendirilmediği yönünde pek çok örnek mevcuttur. Mesela murâbaha işleminde malın alınması ve satılması aşamasında vekalet akdinin klasik fikıhtan kopyalanmak suretiyle taşınması ve bağlamı içinde işleme etkisinin yeterince değerlendirilmemesi bu duruma örnek

38 Bu yönde bir değerlendirme için bk. Kilian Bälz, Sharia Risk? How Islamic Finance Has Transformed Islamic Contract Law, Cambridge, MA: Islamic Legal Studies Program Harvard Law School, 2008, s. 12-13. Bu durumun murâbaha dışında da etkin olduğu düşüncesi için bk. Cebeci, "Change in the Practice of Ijtihad”, s. 156. 
gösterilebilir. Böyle bir düşünce bizi, farklı "caiz”lerin bir araya gelmesi durumunda, bağlamı dikkate alınmadan her zaman caiz olması hükmüne götürür ki bu yanlış bir çıkarımdır.

Modern işlemler için klasik fıkıh temelinde çıkarımlar yapılırken akitlerin sosyal bağlam, etki ve fonksiyonlarının gerektiği kadar dikkate alınmadığı görülmektedir. Örneğin bir akit ele alınırken genelde topluma, gelir dağılımına, işsizliğe vb. etkileri yeterince tartışılmamaktadır. Bu bakış açısı günümüzde modern murâbahanın sosyo-ekonomik fonksiyonlarının eleştirilmesinde etkili olan unsurlardan biridir. ${ }^{39}$

Murâbaha bağlamındaki çözüm arayışlarında toplumsal ve iktisadi baskıların yanı sıra dış dünyadan (özellikle Batıdan) kaynaklanan unsurların da etkisi vardır ve bu durum araştırmacıların zihninde ideolojik ve psikolojik bir baskı oluşturmaktadır. Bundan hareketle, murâbaha ve diğer işlemlere çözüm bularak bu işlemlerin sürekliliğini sağlama hedefinin ve bu şekilde hem faizli bankalara ve hem de bir bütün olarak Batıyya karşı ayakta kalma düşüncesinin klasik fikha yaklaşımlarda da etkili olduğu ifade edilebilir.

Klasik fıkıhta var olan işlemlerin daha yalın bir yapıda olduğu ve iktisadi işlemlerin ve özellikle murâbahanın çok aşamalı hale gelmesi ile iki tür arasında pek çok farkın orta çıktığı görülmektedir. Böyle bir durum karşısında modern murâbahayı klasik murâbahanın devamı gibi değerlendirmek ve doğrudan benzerlik ve paralellikler kurmak sıhhatli değildir.

Murâbahanın ortaya çıkış sürecinin başında klasik fikha daha yakın bir çizginin hedeflendiği ama adım adım bu çizgiden uzaklaşıldığı görülmektedir. Bu değişimde (veya kaymada), modern Müslüman toplumlarda giderek daha fazla egemen olan kapitalist hayat anlayışı ve tüketim kültürü, ahlaki alandaki problemler, rekabet unsuru ve teknolojik gelişmeler etkili olmuştur. Örneğin daha önceki dönemlerde elektronik işlemler sınırlı iken son yıllarda özellikle iletişim araçları internetin yaygınlaşmasıyla birlikte işlemlerin elektronik ortamda yapılması mümkün hale gelmiş ve mesela 'hükmî kabz' gibi uygulamaların temelleri de bu bağlamda araştırma konusu olmuştur.

Murâbaha ile ilgili çıkarımlarda klasik fıkıhtaki işlemlerle benzerlik kurma eğilimine zaman zaman rastlanmaktadır. Örneğin, istisnâ', selem, müzayede, cuâle, hıyâru'l-ayb kefalet-i derek ve bey' 'u'l-îne akitleri klasik fıkıhtan getirilen örnekler olarak kullanılmaktadır.

Geçmişte kişiler arasında yapılan pek çok işlemin bugün kurumsal olarak uygulandığı bir gerçektir. Klasik fikıhla yapılan mukayeselerde de bugünkü kurumsal ve idari yapının ve işleyişin dikkate alındığı ve bunun kabul gördüğü görülmektedir. Örneğin, murâbaha işleminde kanunların belirleyiciliği, bankanın murâbaha kaynaklık eden sermayeyi müşterilerden toplaması ve sistemin ayakta kalması için kârlı işlemler yapmanın gerekli olması gibi yeni unsurların klasik fikıhtaki kabullerden farkları araştırmacılarca tabii kabul edilmektedir.

39 Faizsiz bankaların sosyal fonksiyonlarındaki eksikliklerin murâbaha ile ilişkisi için bk. İsmail Cebeci, "Integrating the Social Maslahah into Islamic Finance", Accounting Research Journal, 2012, XXV, sy. 3, s. 175-7. 
Doğrudan mezheplere atıflar çok olmakla birlikte mezhep birikiminin ve verilen hükümlerdeki arka planın göz ardı edilmesi eleştirilmektedir. Zira bu durum akdin bağlamının göz ardı edilmesine yol açabilmektedir.

Murâbaha bağlamında verilen bazı hükümler zaruret sebebiyle istihsanı çağrıştırmaktadır. Geçmişe kıyas edilen bazı meseleler, benzer gibi görünse de değişen şartlar dolayısıyla farklı özellikler taşımakta ve bunun sonucunda kıyas dışında bir yolla hüküm üretilmektedir.

Klasik fıkha yaklaşımlarda mer'î kanunların etkili olduğu ve çözüm arayışlarında bu hususun da dikkate alındığı görülmektedir. Mesela bir akdin uygulanması ile ilgili olarak kanuni bir problem varsa farklı başka çözümler aranmakta veya zarurete binaen hüküm verilmektedir. Örneğin ülke kanunlarının, bankanın murâbaha konusu malı resmî olarak alıp satmasını geçerli kabul etmemesi durumunda bu tür yaklaşımlarla karşılaşılmaktadır. ${ }^{40}$

Diğer pek çok işlemde olduğu gibi murâbahaya ilişkin üretilen hükümlerde de toplu ictihad faaliyetinin etkisi görülmektedir. Bu tür bir hüküm üretme ameliyesinde de klasik fikıh mirası etkili olmuştur. Örneğin Mecma'u'l-fikhi'l-̇slâmî gibi kurumların sunum ve müzakerelerinde klasik fikıh kaynakları temel referanslar arasında yer almaktadır.

Bu tespitler 1şığında, "Modern murâbaha akdinin oluşum ve gelişiminde ortaya çıkan hükümlerin üretim sürecinde, klasik fıkıh mirası ile sağlıklı ve tutarlı bir ilişki biçiminin varllğından söz edilebilir mi?” sorusuna cevap olarak şu olumlu ve olumsuz hususlar zikredilebilir:

Yeni meselelerin çokça ortaya çıktığ faizsiz finans alanında ve özellikle murâbaha işlemi bağlamında klasik fikıh mirası ile canlı bir ilişkinin devam ediyor olması; fıkhî çözüm yolu arayanlar içinde önemli bir kesimin fikıh mirasını donmuş bir malzeme olarak görmemeleri ve büyük oranda değişimin farkında olunması; bu alanda fikir üreten hemen herkesin mezhep taassubundan uzak bir şekilde arayışta olmaları ve murâbahanın da içinde bulunduğu muamelat/İslâm İktisadı alanının hukukunun diğer alanları için de örnekler içermesi, çağdaş fakihlerin klasik fikıh mirası ile ilişkilerinde olumlu noktalar olarak değerlendirilebilir.

Diğer yandan, belli noktalarda klasik fikhın realiteye nasıl yansıtılacağ 1 hususundaki belirsizlik; klasik fıkıhla irtibatın, ideal çözümler yerine günü kurtaran kısa vadeli çözümler üzerine yoğunlaşabilmesi; usulden ziyade fürû temelli ve sürekli pratikten hareketle klasik fikıhtan hüküm arayışının zaman zaman tutarsızlıklara sebep olması; pratik işleyişin getirdiği baskılar sonucu bakış açısının zaruret mantı̆̆ üzerine oturtulması ve bunun gerçek durumun anlaşılmasına belli bir derecede engel olması; "Eşyada aslolan ibâhadır" kaidesine rağmen klasik fikıh şablonlarını aşmama anlayışı, klasik fikıh metinlerinden "kes yapıştır" mantığının varlığı, bazı hükümlerde klasik-modern arası değişen bağlamın farkına varamama ve bütüncül bakış açısından yoksunluk (minimalist yaklaşım) klasik fikha bakışla ilgili olumsuz noktalar olarak zikredilebilir.

40 Murâbahanın kanuni açıdan değerlendirilmesi için bk. Cemal Atıyye, "el-Cevânibü'l-kânûniyye li-tatbîki akdi'l-murâbaha”, Mecelletü Câmiatil-Melik Abdülaziz (el-İktisâdü'l-İslâmî), 1990, II, s. 125-46. 


\section{Sonuç: Klasik Fıkıh Mirasıyla Sağlıkı Bir İlişki İçin Dikkat Edilecek Hususlar}

Modern dönemde belli bir alandaki hüküm üretme faaliyetlerinin fikıh mirası ile ilişkisini değerlendirmek ve gelinen noktayı tespit etmek her sahada gerçekleştirilmesi gereken bir hedef olmalıdır. Bu çalışmada değinilen konular sadece murâbaha ile değil, modern dönemde İslâm iktisadının ve hatta diğer alanların pek çok meselesi ile de yakından ilgilidir. Bu itibarla, çağdaş fakihlerin fikıh mirası ile ilişkisi açısından hem murâbaha akdi bağlamında spesifik hem de İslâm Hukuku ile ilgili genel sonuçlara ulaşılmaya çalışılmıştır. Çalışma kapsamında murâbahanın süreç ve yapı bağlamında klasik fıkıhla ilişkisi, murâbahanın modernize edilmesi sürecinde fakihlerin zihin dünyaları ve klasik fikha yaklaşım tarzları ve mezhep algısının konuya etkisi incelenmiş, konuya ilişkin çıkarımlarda bulunulmuş ve olumlu-olumsuz yönler değerlendirilmiştir.

Klasik fikhı nasıl değerlendirdiğimiz, yaşadığımız dünyada kendimizi nasıl konumlandırdığımızı görme açısından da önemli bir ölçüttür. Bu bağlamda klasik fikıh metinlerine her durumda kutsiyet atfetmek veya bu değerli mirası yok saymak bizi farklı problemlerin içine itecektir. Gösterilmesi gereken tavır, bu mirasla sağlıklı bir ilişki kurmak ve yeni problemler karşısında tutarlı hükümler ve çözüm yolları üretebilmektir.

Klasik fıkıh metinlerinin doğru bir şekilde yorumlanması, Müslümanların sosyal tarih birikiminin bilinmesi ile yakından ilgilidir. Bir fikıh metninin ve metinde yer alan hükümlerin oluşmasında pek çok unsur etkili olmuş olabilir. Örneğin ele alınan metnin kaleme alındığ 1 yer ve dönemdeki sosyal yapı, şehrin konumu ve güvenliği, mimari özellikler, askeri yapı, kadın-erkek ilişkileri, siyasi otoritenin tutumu, bizzat metni kaleme alan fakihin konumu ve ilişkileri ve toplumun ticari yapısı gibi unsurlar metnin oluşumu üzerinde ziyadesiyle etkili olmuş olabilir. Bundan dolayı, 'klasik fikıh metni' tabirini ele alırken yeknesak bir zaman ve mekan anlayışına sahip olmak yanıltııı olabilir. Zira karşımızda on asrı aşkın bir süre içinde pek çok farklı zaman diliminde ve coğrafyada oluşan bir metinler birikimi söz konusudur. Bundan dolayı, fikıh eserleri üzerinden yapılan çıkarımlarda bağlama dikkat edilmesi ve özellikle incelenen konuyu etkileyen faktör ve değişimlerin anlaşılması çok önemlidir. Fıkıh metinleri, hukuk kaynağı olduğu gibi aynı zamanda Müslümanların sosyal hayatını ve değişimi de yansıtan zengin kaynaklardır. Bu yönlerin de ihmal edilmemesi gerekir. Aksi takdirde klasik fikıhta toplumsal şartların, insanın eşya ile ilişkisinin, üretim tarzının farklı olduğu bir dünya ile bugün arasında doğrudan benzerlikler kurmak bizi yanlı̧s sonuçlara götürebilir.

Müslümanların karşı karşıya kaldığı problemlerin çözümünde klasik fikıh mirasımız tabi ki çok önemli bir role sahiptir ve fikhın diğer alanlara öncülük etmesi gerektiği ifade edilebilir. Ancak diğer klasik ilimlerle ilişkilerin de önemli olduğu gözden kaçırılmamalıdır. Klasik fikıh metinleri gibi klasik tarih, coğrafya, ahlak, felsefe, mimari, siyaset metinleri de bir bütünün parçalarıdır. Geçmişle bugün arasında sağlıklı bir bağ kurarak yaşadığımız dünyaya karşı tutarlı çözümler üretmek bu birikim ve mirasın bir bütün halinde değerlendirilmesiyle mümkün olacaktır. Bu itibarla yeni problemler karşısında fakihlerin yanı sıra 
siyaset, ekonomi, tarih, sosyoloji ve mimari gibi alanlardaki ilim erbabının da katkısı kaçınılmazdır. Unutulmamalıdır ki İslâm tarihinde her alandaki tarihi tecrübe bizi köksüzlükten koruyan zengin kaynaklar ve bilgi birikimi demektir.

Murâbahanın klasik fıkıhla ilişkisini irdeleyen bu tarz çalışmaların mikro planda mudârabe, müşâreke ve icâre gibi diğer akit modelleri ve makro planda günümüzde tartışılan iktisadî, sosyal, siyâsî vb. diğer meseleler için de yapılması gerekir. Ancak bu çabalar yoluyla tarihi tecrübe ile sağlıklı bir ilişki kurmak ve yeni meselelerin klasik fıkıhla ilişkisi üzerinden bütüncül, sağlıklı ve tutarlı bir resim ortaya koymak mümkün olacaktır. 


\section{Kaynaklar}

Abozaid, Abdulazeem. "Role of Fiqh in Islamic Finance." İslâm İktisadı Atölyesi-1: Temel Kavramlar ve Fikirleri 2-3 Mart, Istanbul-Türkiye. y.y, t.y, s. 37-53.

Atıyye, Cemal. “el-Cevânibü’l-kânûniyye li-tatbîki akdi'l-murâbaha.” Mecelletü Câmiati'l-Melik Abdülaziz (el-İktisâdü’l-̇̇slâmi), 1990, II, s. 125-46.

Bälz, Kilian, Sharia Risk? How Islamic Finance Has Transformed Islamic Contract Law. Cambridge, MA: Islamic Legal Studies Program Harvard Law School, 2008.

Boynukalın, Mehmet. İmam Muhammed b. Hasan eş-Şeybânînin Kitâbü’l-Asl Adlı Eserinin Tanıtımı ve Fıkıh Usulü Açısından Tahlili. İstanbul: Ocak Yayınları, 2009. s, 69-70.

Cebeci, İsmail. "Change in the Practice of Ijtihad: The Case of Islamic Finance." Ilahiyat Studies, 2012, III, sy. 2 , s. 149-171.

------ "Integrating the Social Maslahah into Islamic Finance." Accounting Research Journal, 2012, XXV, sy. 3, s. 166-184.

-------. Modern İslâm İktisadı Literatüründe Murâbaha Tartışmaları (doktora tezi, 2010). Marmara Üniversitesi Sosyal Bilimler Enstitüsü.

Duman, Soner. "Günümüz Fıkhî-İktisadî Problemlerin Değerlendirilmesinde Fıłıh Mirasımız İle İlişki Biçimimiz.” Uluslararası İslâm Ekonomisi ve Finansı Araştırmaları Dergisi, 2015, I, sy. 1, s. 153-170.

Ebû Zeyd, Abdülazîm. Bey'u'l-murâbaha ve tatbîkâtühü'l-muâsıra fi'l-mesârifi'l-İslâmiyye. Şam: Dâru'l-fikr, 2004.

Ebü’l-Besal, Abdünnasır. "Menhecü'l-fetvâ fi'l-ahkâmi'l-muâsıra” Ebhâsü’l-Yermûk, Haziran 2002, XVIII, sy. 2B, s. 449-484.

Feyyaz, Atıye Seyyid. et-Tatbikâtü'l-masrafiyye li-bey'i'l-murâbaha fî dav'i'l-fikhi'l-İslâmî. Kahire: Dârü'nNeşr li'l-Câmiât, 1999/1419.

Hammûd, Sami Hasan. Tatvîru'l-a'mâli'l-masrafiyye bimâ yettefiku veş-şerîate'l-İslâmiyye (doktora tezi, 1976), Kahire Üniversitesi, 1976.

Haseneyn, Feyyaz Abdülmünim. Bey'u'l-murâbaha fi'l-mesârifi'l-İslâmiyye. Kahire: el-Ma'hedü’l-âlemî li'lfikri'l-İslâmî, 1996.

Haydar, Ali. Dürerü’l-hükkâm şerhu Mecelleti'l-Ahkâm. İstanbul: Matbaa-i Tevsi-i Tibâat, 1330, I.

Hûce, İzzeddin. ed-Delîlüşs-şer î li’l-murâbaha (tsh. Abdüssettâr Ebû Gudde). Cidde: Mecmû́atü Delleh elBereke, 1998.

İbn Âbidin, Muhammed Emin b. Ömer b. Abdülazîz ed-Dımeşkî. Reddü'l-muhtâr ale'd-Dürri'l-muhtâr şerhu Tenvîri'l-ebsâr Hâşiyetu İbn Âbidin (nşr. Âdil Ahmed Abdülmevcûd - Ali Muhammed Muavvaz). Riyad: Dâru Âlemi'l-Kütüb, 1423/2003.

İbnü’l-Hümâm, Kemalüddin Muhammed b. Abdülvâhid b. Abdülhamîd es-Sivâsî el-İskender. Şerhu Fethi'lkadir. [y.y.], 1389/1970.

el-Kardavî, Yusuf. Bey'u'l-murâbaha li'l-âmir bişsşirâ kemâ tücrîhi'l-mesârifüll-İslâmiyye. Kahire: Mektebetü Vehbe, 1987.

Mecelle-i Ahkâm-ı Adliyye. İstanbul: Hikmet Yayınları, 1982.

el-Merginânî, Ebü'l-Hasan Burhaneddin Ali b. Ebî Bekir. el-Hidâye şerhu Bidâyetül-mübtedî (nşr. Muhammed Muhammed Tamir - Hafız Aşur Hafız). Kahire : Dârü's-selam, 2000.

el-Misrî, Refik Yunus. “Bey'u'l-murâbaha li'l-âmir bişş̧irâ kemâ tücrîhi'l-mesârifü'l-İslâmiyye.” Mecelletü’lümme, Muharrem 1406 / Eylül 1985, sy. 61, s. 25-28. 
------. “Bey'u'l-murâbaha li'l-âmir bi’şşirâ fi'l-mesârifi'l-İslâmiyye.” Mecelletü Mecma'i'l-fikhi'l-İslâmî, 1988V, sy. II, s. 1127-79.

------. Bey'u'l-murâbaha li'l-âmir bişs-şirâ fi'l-mesârifi'l-İslâmiyye, Beyrut: Müessesetü’r-risâle, 1996.

Mülhim, Ahmed Sâlim. Bey'u'l-murâbaha ve tatbikatühü fi'l-mesârifi'l-İslâmiyye. Amman: Dâru's-sekâfe, 2005.

eş-Şâfiî, Ebû Abdullah Muhammed b. İdris b. Abbâs. Kitâbü'l-Ümm - Mevsûatü’l-İmam eş-Şafî̀ (nşr. Ali Muhammed - Âdil Ahmed). Beyrut: Dâru ihyâi't-türasi'l-Arabî, 1422/2001.

eş-Şeybânî, Ebû Abdillâh Muhammed b. el-Hasan b. Ferkad. el-Mehâric fi'l-hiyel. Kahire: Mektebetü’sSekâfeti'd-Diniyye, ts.

ez-Zeylâî, Fahreddin Osman b. Ali b. Mihcen. Tebyînü’l-hakâikfî şerhi Kenzid-dekâik. Bulak: el-Matbaatü’lkübra'l-Emiriyye, 1314. 
